\title{
Nutritional and Technological Optimization of Wheat-Chickpea- Milk Powder Composite Flour and Its Impact on Rheological and Sensorial Properties of Leavened Flat Bread
}

\author{
Aouatif Benali ${ }^{1,2, * \mathbb{D}}$, Youness En-nahli ${ }^{3}$, Younès Noutfia ${ }^{1}{ }^{(D}$, Adil Elbaouchi $^{4}$, Mohammed Rachid Kabbour ${ }^{1}$, \\ Fatima Gaboun ${ }^{1}$, El Haj El Maadoudi ${ }^{1}$, Nadia Benbrahim ${ }^{1}$, Mona Taghouti ${ }^{1} \mathbb{D}$, Mohammed Ouhssine ${ }^{2}$ \\ and Shiv Kumar $3, *$ (D)
}

check for updates

Citation: Benali, A.; En-nahli, Y.; Noutfia, Y.; Elbaouchi, A.; Kabbour, M.R.; Gaboun, F.; El Maadoudi, E.H.; Benbrahim, N.; Taghouti, M.; Ouhssine, M.; et al. Nutritional and Technological Optimization of Wheat-Chickpea- Milk Powder Composite Flour and Its Impact on Rheological and Sensorial Properties of Leavened Flat Bread. Foods 2021, 10, 1843. https://doi.org/10.3390/ foods 10081843

Academic Editor: Antonio Piga

Received: 7 July 2021

Accepted: 4 August 2021

Published: 10 August 2021

Publisher's Note: MDPI stays neutral with regard to jurisdictional claims in published maps and institutional affiliations.

Copyright: (c) 2021 by the authors. Licensee MDPI, Basel, Switzerland. This article is an open access article distributed under the terms and conditions of the Creative Commons Attribution (CC BY) license (https:// creativecommons.org/licenses/by/ $4.0 /)$
1 National Institute of Agricultural Research (INRA), Rabat-Instituts, Rue Hafiane Cherkaoui, Agdal 10101, Morocco; younes.noutfia@inra.ma (Y.N.); mohammedrachid.kabbour@inra.ma (M.R.K.); fatima.gaboun@inra.ma (F.G.); elhaj.elmaadoudi@inra.ma (E.H.E.M.); nadia.benbrahim@inra.ma (N.B.); mouna.taghouti@inra.ma (M.T.)

2 Biology Department, Faculty of Sciences-Ibn Tofail University, Kenitra 14000, Morocco; ouhssineunivit@gmail.com

3 International Center for Agricultural Research in the Dry Areas (ICARDA), Rabat 10101, Morocco; youness.ennahli@gmail.com

4 African Integrated Plant and Soil Research Group (AiPlaS), AgroBioSciences, Mohammed VI Polytechnic University, Ben Guerir 43150, Morocco; adil.elbaouchi@um6p.ma

* Correspondence: Aouatif.benali@inra.ma (A.B.); sk.agrawal@cgiar.org (S.K.)

\begin{abstract}
Flour quality is influenced by the nature of the gluten and its various components. Gluten free flour made of pulses is known to enhance the nutritional quality of wheat flour. However, its addition can compromise the rheological and sensorial attributes of the bread. We used mixture design to optimize nutritional and technological qualities of a wheat-chickpea flour blend by adding milk powder as a natural organoleptic improver. A total of thirteen flour blends were prepared by incorporating 10 to $30 \%$ chickpea flour and 10 to $20 \%$ milk powder to wheat flour. Our results showed that the optimal flour blend consisted of $60 \%$ wheat, $24 \%$ chickpea, and $16 \%$ milk powder. Farinographic parameters of the optimal dough blend remained on par with those of the control dough (100\% wheat flour), thereby preserving its bread-making quality. Sensory analysis of breads made from the optimal flour blend revealed no significant difference $(p \leq 0.05)$ from wheat flour for crumb and chewiness. Appreciation was brought to the appearance, crust, aroma, and taste in the optimized bread. This study suggests that chickpea flour can be suitably incorporated into bread wheat flour up to a percentage of $24 \%$ with $16 \%$ milk powder to produce bread with optimal nutritional quality while improving its sensory attributes and consumer acceptability.
\end{abstract}

Keywords: flat bread; mixture design; chickpea; milk powder; nutritional fortification; organoleptic enhancement

\section{Introduction}

Pulses are increasingly being recognized worldwide as healthy foods [1]. They are good sources of protein, vitamins, minerals, and beneficial dietary fibers for human gut health $[2,3]$. The World Health Organization (WHO) has recommended the frequent consumption of pulses in order to reduce serum cholesterol levels and the risks of coronary heart disease and cancer in humans [4]. This unique nutritional and health potential imparts upon pulses an important role to address issues related to the triple burden of malnutrition. Thus, the FAO of the United Nations Organization celebrated 2016 as the International Year of Pulses [5] with the aim of drawing attention to the nutritional and health benefits of pulses and strengthening the paradigm shift towards including more of this nutritional powerhouse in diets all over the world [6]. In this context, systemic 
attention has been given to the research of new technologies for introducing them into cereal-based foods as healthy ingredients. Pulses, especially when blended with cereals, offer a promising alternative source for nutritional and functional proteins and will carry nutritional benefit to a wide range of the population that is increasingly interested in pulse utilization [7]. The addition of pulse flour into wheat flour is a difficult task from a technological point of view because of the absence of gluten [8] as well as in relation to sensory properties, in particular, flavor and texture, which are very important in the developed world, where consumers have extremely discriminating tastes [1].

Chickpea (Cicer arietinum L.) is an important grain legume with a multitude of nutritional and health benefits [9]. Indeed, it contains a high proportion of non-digestible carbohydrates and contains a rich variety of phytochemicals, including natural antioxidants such as phenolic or flavonoid compounds that decrease oxidative stress and inflammation related to many chronic ailments $[10,11]$. The fortification of bakery products with chickpea flour has already been employed and appears to be promising in particular for the functional food market [12]. The addition of chickpea flour to wheat flour improves the quality of protein, fiber, and mineral content of the bread. Unfortunately, a threshold of 5 to $10 \%$ of chickpea flour is imposed in order to not lose some organoleptic qualities such as chewiness [13-15], limiting the nutritional improvement that this legume could bring to bread. This is mainly due to gluten dilution caused by the addition of chickpea flour into wheat flour. In fact, a low content or a lack of gluten may deteriorate bread quality given that gluten is a protein of major importance in baked products because of its contribution to the viscous and extensibility properties that positively influence the overall quality of bread making [16,17].

Milk powder is widely used in bread formulation due to its nutritional and technological roles $[18,19]$. Its incorporation into gluten free products is all the more accentuated given the distinguished quality of its ingredients, in particular, proteins and minerals ensuring a network development similar to that formed by the gluten, ensuring dough stability [20]. It also improves the mouth feel and the overall acceptability of the formulated breads [21]. For this double role, milk powder was used as a third ingredient with the objective of optimizing the nutritional and technological quality of wheat-chickpea flour blend through the mixture design methodology. Rheological and sensorial qualities of the optimized dough mixture and bread were assessed and compared to bread wheat as a control.

\section{Materials and Methods}

\subsection{Raw Material}

In this study, bread wheat (Triticum aestivum) of the 'Khadija' variety and chickpea (Cicer arietinum) of the 'Farihan' variety that is widely grown in Morocco were used for flour blend preparation. The milk powder that was used was of a known international trademark. After cleaning and the removal of foreign impurities, wheat grains were thoroughly milled in a laboratory pilot mill (BUHLER-Switzerland) with a sieve of $250 \mu \mathrm{m}$ that was set at a $64.5 \%$ extraction rate. Chickpea grains were ground by a hammer mill (IKA, Königswinter, Germany) with a sieve of $1 \mathrm{~mm}$. All of the ingredients were stored properly until needed.

\subsection{Blend Preparation and Mixture Experimental Design}

In order to optimize the flour mixture of bread wheat (A), chickpea (B), and milk powder $(C)$ from nutritional and technological points of view, the experimental design approach that was adopted was mixture design. This approach has the advantage of rationalizing analysis cost, time, and efficiency by reducing the number of experiments and giving maximum information on the constituents, their influences taken separately, and on their eventual interactions [22]. The mixing experimental design was used during the last few years to study the formulation in many food industries for several quality purposes [23]. Regarding flour blending, it has been used for both nutritional purposes enrichment [24,25] and for improving functional quality [26,27]. 
Preliminary tests defined the study area by setting the lower and upper limits as $60-80 \%$ for wheat flour, $10-30 \%$ for chickpea flour, and $10-20 \%$ for milk powder. The experimental matrix (scheffe matrix) obtained was composed of 13 blend combinations in which the ingredient quantities were within the above set limits. Responses to parameters concerning the nutritional composition were proteins, crude fat, carbohydrates, total polyphenol compounds (TPC), antioxidant activity and mineral content (Fe, Zn and P), and the technological parameters were the zeleny volume and the yellow index $\left(\mathrm{b}^{*}\right)$. Trace plot curves and 2D and 3D response surface presentations allowed for the visualization of the effect of variability of one ingredient on the responses while the other two ingredients were fixed.

\subsection{Nutritional Composition Analysis}

Chickpea flour, bread wheat flour, and their blends with milk powder were subjected to protein content analysis using the Kjeldahl method and crude fat analysis by diethyl ether extraction using a soxhlet apparatus. The available total carbohydrates were determined by difference calculations. All of these analyses were performed according to the official methods of analysis of the Association of Official Analytical Chemists (AOAC) [28].

\subsubsection{Mineral Content}

Total Fe, Zn, and P concentrations in different flour blends were determined using the nitric acid-hydrogen peroxide digestion method [29,30]. Mineral concentrations were measured through inductively coupled plasma-optical emission spectroscopy (ICP-OES); (ICP-7000 Duo, Thermo Fisher Scientific, Waltham, MA, USA).

\subsubsection{Total Phenolic Content}

The total phenolic content of flour blends was determined following the method of Singleton and Rossi [31] using the Folin-Ciocalteu phenol reagent. A total of one gram of the blend flour was extracted for $4 \mathrm{~h}$ with $20 \mathrm{~mL}$ of $80 \%$ ethanol. The mixture was centrifuged at $2000 \mathrm{RPM}$ for $15 \mathrm{~min}$, and $200 \mu \mathrm{L}$ of the extract was mixed with $1 \mathrm{~mL}$ of Folin-Ciocalteu reagent (previously diluted 10-fold with distilled water) and was allowed to stand at room temperature for $4 \mathrm{~min}$. A total of $800 \mu \mathrm{L}$ of sodium bicarbonate $(7.5 \mathrm{~g} / \mathrm{L})$ solution was then added to the mixture. After $2 \mathrm{~h}$ of incubation in darkness at room temperature, the absorbance was measured at $765 \mathrm{~nm}$. The results were expressed as the $\mu \mathrm{g}$ Gallic Acid Equivalent (GAE) per gram of dry matter.

\subsubsection{Estimation of DPPH Scavenging Activity}

For each flour blend extract, DPPH scavenging activity was evaluated according to the method described by Brand-Williams et al. [32]. A total of $200 \mu \mathrm{L}$ of each blend extract at different concentrations was added to $1.8 \mathrm{~mL}$ of a methanolic solution of 2,2-Diphenyl-1picrylhydrazyl (DPPH) $(0.025 \mathrm{~g} / \mathrm{L})$. A negative control was prepared by mixing $50 \mu \mathrm{L}$ of methanol with $1.95 \mathrm{~mL}$ of the methanolic solution containing DPPH. The absorbance of each supernatant was measured against the negative control at $517 \mathrm{~nm}$ after $30 \mathrm{~min}$ of incubation in darkness at room temperature. The estimation of the DPPH scavenging activity was calculated as follows:

$$
\% \text { ScavengingActivity }=\left[\frac{\mathrm{cAbs}-\mathrm{sAbs}}{\mathrm{cAbs}}\right] \times 100
$$

where $c$ Abs represents the negative control absorbance, and $\mathrm{s}$ Abs represents sample absorbance.

\subsection{Determination of Technological Quality Parameters}

The yellow index $\left(b^{*}\right)$ of flour blend samples was measured using a Chroma Meter CR-400 (Konica Minolta-Carrieres-sur-seine, France). The instrument was calibrated against a white calibration plate. In addition, gluten strength was determined using 
the sedimentation volume-Zeleny volume according to the international standard ISO 5529 [33]. The results were expressed as the sedimentation volume $(\mathrm{mL})$ of the flour blends in a lactic-isopropanol solution.

\subsection{Optimal Blend}

The optimal combination of the studied responses was obtained by 'the desirability function' as outlined by Derringer and Suich [34]. This purely mathematical procedure consists of simultaneously seeking the maximum of all the answers by the following formula:

$$
\operatorname{Dg}(\text { blend })=\sqrt[n]{(d 1 \times d 2 \times d 3 \times \ldots \times d n)}
$$

where $\mathrm{Dg}$ is the overall desirability of the flour mixture, and di refers to the individual desires of the ingredients.

\subsection{Rheological Quality and Bread Making Procedure of the Optimal Flour Blend}

The optimal flour blend was analyzed by a farinograph (Brabender farinograph $\odot$ Pfullingen, Germany) and was subjected to bread making against a control flour (100\% bread wheat). Absorption, stability, and other characteristics of the dough were determined by farinograph curves according to the AACC method 54-21 [35].

\subsection{Breadmaking}

Flat breads obtained with the optimized blend and control flours were prepared and baked using the straight dough method. A total of $1 \mathrm{~kg}$ of flour from each sample was mixed with $2 \%$ lyophilized yeast and $1 \%$ salt. The added water volume corresponded to the maximum absorption given by the farinograph, and the kneading was realized by a spiral mixer (100-200 RPM). The dough was then fermented for $90 \mathrm{~min}$ at $30^{\circ} \mathrm{C}$, divided to $150 \mathrm{~g}$ round pieces, and was allowed to rest at $30^{\circ} \mathrm{C}$ for $11 \mathrm{~min}$. Each piece was manually sheeted to a round shape of a 1 to $2 \mathrm{~cm}$ thickness, panned, and proved for $45 \mathrm{~min}$ at $30^{\circ} \mathrm{C}$. The bread was baked at $240{ }^{\circ} \mathrm{C}$ for $20 \mathrm{~min}$ [36].

\subsection{Sensorial Analysis of the Optimal Blend Bread}

Sensory evaluation of baked breads was conducted for six defined quality attributes: appearance, chewiness, aroma, crust, crumb, and overall taste by a panel of 30 semitrained members (employees of a catering company, researchers, and students) on a 9-point hedonic scale [37].

\subsection{Statistical Analysis}

A statistical test of the mixture design was conducted using Design Expert Software v11. The model response fitting was verified by the ANOVA test, analyzing the $f$ and $p$ value $(p \leq 0.05)$, the smallest standard error, the smallest mean, and the sum of the predicted deviations, and maximizing the $R^{2}$ and the adjusted $R^{2}$ [38]. The highest polynomial orders with significant additional terms were selected. The optimality was assessed by the D-optimal algorithm, and all ingredients were designed as dependent variables by the relation $\mathrm{A}+\mathrm{B}+\mathrm{C}=1$. The entirety of the experiments were conducted in triplicate, and the differences between treatment means were determined by Duncan's multiple range test $(p \leq 0.05)$ using SPSS statistics 17.

\section{Results and Discussion}

\subsection{Nutritional Composition of Flour Mixtures \\ 3.1.1. Macronutrient Content}

The significance of proteins, carbohydrates, and lipids of the flour mixtures was investigated according to the $\mathrm{F}$ test and $p$ value analysis, and all followed a linear model (Table 1). Factor coefficient assessment showed that protein was significantly influenced by the rate of chickpea flour and milk powder incorporation with maximum value of 
$15.83 \mathrm{~g} / 100 \mathrm{~g}$ DM in the mixture consisting of $60 \%$ bread wheat, $25 \%$ chickpea, and $15 \%$ milk powder (Table 2). The lipids increased with the increase of milk powder, ranging from 4.31 to $8.98 \mathrm{~g} / 100 \mathrm{~g}$ DM (Figure 1). In contrast, carbohydrates were more influenced by the rate of bread wheat, ranging from 63.89 to $69.99 \mathrm{~g} / 100 \mathrm{~g}$ DM (Table 2). These findings agree with the work of Ouazib et al. [39], who demonstrated that the enhancement of the protein and lipid content of the flour blends was a direct result of the typical composition of chickpea flour that is rich in protein and lipids and that is especially rich in polyunsaturated fatty acids. Likewise, milk powder also enhanced total the protein and lipid content [40,41].

\subsubsection{Mineral Composition}

Micronutrient response equations were not all of linear order and proved the significance of nonlinear terms. Phosphorus was the only element following a linear order equation $(p=0.0055)$. Coefficient analysis demonstrated a significant enrichment effect of chickpea flour and milk powder on phosphorus in the blend flours (Table 1) ranging from 206.4 to $6419.2 \mathrm{ppm}$. The maximum value was recorded for the mixture composed of $60 \%$ wheat, $20 \%$ chickpea, and 20\% milk powder (Table 2).

The $p$ value and $\mathrm{F}$ test showed that the equations for $\mathrm{Fe}$ and $\mathrm{Zn}$ content were of quadratic order ( $p \leq 0.0001$ for $\mathrm{Fe} ; p=0.0002$ for $\mathrm{Zn}$ ). Analysis of the linear terms of the $\mathrm{Fe}$ and $\mathrm{Zn}$ regression equations revealed that the iron content of a blend was more influenced by the rate of incorporated chickpea flour, while the $\mathrm{Zn}$ content was more influenced by the milk powder rate, demonstrating the highest concentration of $48 \mathrm{ppm} \mathrm{Zn}$ and $57.60 \mathrm{ppm}$ Fe in the blend of $60 \%$ bread wheat, $20 \%$ chickpea, and $20 \%$ milk powder. The $p$ value and $\mathrm{F}$ test of the quadratic terms of the two equations confirmed significant positive values of the partial factor (BC), which demonstrates the synergistic effect of the interaction between chickpea flour and milk powder for the maximum Fe enrichment of the mixture. Fe ranged from 33.60 to $57.60 \mathrm{ppm}$, and the maximum value was reported in the mixture of $60 \%$ bread wheat, $30 \%$ chickpea, and $10 \%$ milk powder. This interaction was insignificant for $\mathrm{Zn}$, which can be visualized in the trace plot curves and response surface presentations (Figure 2).

The negative value of the partial factor $\mathrm{AB}$ of the iron regression equation demonstrated that the interaction between bread wheat and chickpea resulted in the minimum value of this element. The same factor being positive for $\mathrm{Zn}$ demonstrated a synergistic effect between bread wheat and chickpea in the increasing zinc content of the blends. The interaction between bread wheat flour and milk powder was insignificant for the iron content, while it was negative and decreased the $\mathrm{Zn}$ level to minimal levels.

The synergistic effect of chickpea flour and milk powder on the mineral fortification can be justified by the richness of these two ingredients in these micronutrients. Man et al. [13] reported that the addition of $30 \%$ chickpea flour increased the ash content of wheat flour by four times. An increase was observed in the same elements during bread fortification with different dairy products (milk powder, whey protein concentrate powder, and buttermilk powder) with significantly higher levels than wheat bread [41,42].

\subsubsection{Total Polyphenols and Scavenging Activity of Blend Preparation}

The regression equation of the total polyphenolic content was of a special cubic model $(p=0.0045)$ (Table 1). By analyzing the coefficients of the linear terms, the addition of chickpea flour to the blend had the highest effect on enhancing the total polyphenol content followed by bread wheat flour, with a maximum value of $575.95 \mu \mathrm{g} \mathrm{GAE} / \mathrm{g}$ DM in the mixture of $70 \%$ wheat, $20 \%$ chickpea, and $10 \%$ milk powder (Table 2). Significant quadratic terms ( $\mathrm{AC}$ and $\mathrm{AB}$ ) had positive coefficients demonstrating a synergetic effect of binary mixtures on enhancing the content of these bioactive molecules. The ternary mixture $A B C$ had a negative coefficient, which might decrease this response due to dilution with milk powder. These results are in agreement with the graphic representation of this response (Figure 3). 
Table 1. Analysis of the predicted model equations for nutritional and technological quality parameters of wheat-chickpea-milk powder composite flour.

\begin{tabular}{|c|c|c|c|c|c|c|c|c|c|c|c|c|c|c|c|c|}
\hline \multicolumn{2}{|c|}{ Response } & \multirow{2}{*}{$\begin{array}{l}\text { Model } \\
\text { Linear }\end{array}$} & \multirow{2}{*}{$\begin{array}{c}p \text { Value } \\
0.0078\end{array}$} & \multirow{2}{*}{$\begin{array}{c}\mathbf{R}^{\mathbf{2}} \\
0.6211\end{array}$} & \multirow{2}{*}{$\begin{array}{l}\mathbf{R}^{2} \mathbf{a d j} \\
0.5453\end{array}$} & \multirow{2}{*}{$\begin{array}{c}\boldsymbol{F} \text { Value } \\
8.19\end{array}$} & \multirow{2}{*}{\multicolumn{2}{|c|}{$\frac{\text { B }}{14.71^{*}}$}} & \multirow{2}{*}{$\frac{\text { C }}{16.28^{*}}$} & \multicolumn{4}{|c|}{ Prediction Equation (Pseudo Component) } & \multirow{2}{*}{$\mathbf{A}^{2} \mathbf{B C}$} & \multirow{2}{*}{$\mathrm{AB}^{2} \mathrm{C}$} & \multirow{2}{*}{$\mathrm{ABC}^{2}$} \\
\hline & Proteins & & & & & & & & & & & & & & & \\
\hline \multirow{7}{*}{$\begin{array}{c}\text { Nutritional } \\
\text { composition }\end{array}$} & Total carbohydrates & Linear & 0.0005 & 0.7798 & 0.7357 & 17.70 & $69.59 * *$ & 66.02 ** & $61.20^{* *}$ & & & & & & & \\
\hline & Lipids & Linear & 0.0006 & 0.7722 & 0.7266 & 16.95 & $4.27^{* *}$ & $5.32 * *$ & $10.20^{* *}$ & & & & & & & \\
\hline & $\mathrm{p}$ & Linear & 0.0055 & 0.6473 & 0.5767 & 9.18 & $16.74 *$ & $65.87 *$ & $67.82 *$ & & & & & & & \\
\hline & $\mathrm{Fe}$ & Quadratic & 0.0001 & 0.9593 & 0.8980 & 33.03 & $46.95^{* *}$ & $56.59^{* *}$ & $33.68^{* *}$ & $-69.30^{* * *}$ & 40.21 & $46.23 *$ & & & & \\
\hline & $\mathrm{Zn}$ & Quadratic & 0.0002 & 0.9541 & 0.9213 & 29.08 & $33.42 * * *$ & $43.96^{* * *}$ & $52.61^{* * *}$ & 31.81 ** & -44.17 * & -5.43 & & & & \\
\hline & TPC & Special Cubic & 0.0045 & 0.9204 & 0.8407 & 11.56 & $488.3^{*}$ & $553.93 *$ & $440.18^{*}$ & $206.77^{*}$ & $387.88^{*}$ & 207.32 & $-721.51 *$ & & & \\
\hline & Scavenging activity & Special Quartic & 0.0057 & 0.9755 & 0.9264 & 19.87 & $13.06^{*}$ & $22.84 *$ & $50.12 *$ & 16.61 * & -13.74 & $-66.40 *$ & & 350.83 * & 269.23 & -326.58 \\
\hline \multirow{2}{*}{$\begin{array}{l}\text { Technological } \\
\text { parameters }\end{array}$} & Zeleny volume & Linear & 0.0021 & 0.7084 & 0.6539 & 12.15 & $12.89^{*}$ & $10.63 *$ & $8.69 *$ & & & & & & & \\
\hline & Yellow Index $b^{*}$ & Quadratic & 0.0002 & 0.9507 & 0.9155 & 27.01 & $12.69 * * *$ & $17.90 * * *$ & $-7.05 * * *$ & 1.55 & $44.04 * *$ & $44.12 * *$ & & & & \\
\hline
\end{tabular}

${ }^{*}(p$ value $\leq 0.05) ;{ }^{* *}(p$ value $\leq 0.001) ;{ }^{* * *}(p$ value $\leq 0.0001) . \mathrm{R}^{2}$ : Coefficient of determination; $\mathrm{R}^{2}$ adj: Adjusted coefficient of determination; $F$ value: F-test value.

Table 2. Nutritional and technological quality parameters of design mixture experiments with wheat-chickpea-milk powder composite flours.

\begin{tabular}{|c|c|c|c|c|c|c|c|c|c|c|c|}
\hline Exp No. & Run & $\begin{array}{c}\text { Lipids } \\
\text { (g/100 g DM) }\end{array}$ & $\begin{array}{c}\text { Proteins } \\
\text { (g/100 g DM) }\end{array}$ & $\begin{array}{c}\text { Total Carbohydrates } \\
\text { (g/100 g DM) }\end{array}$ & $\begin{array}{c}\text { TPC } \\
\text { ( } \mu \mathrm{g} \text { GAE/g DM) }\end{array}$ & $\begin{array}{c}\text { Scavenging } \\
\text { Activity }\end{array}$ & $\begin{array}{c}\mathrm{Zn} \\
(\mathrm{ppm})\end{array}$ & $\begin{array}{c}\mathrm{Fe} \\
(\mathrm{ppm})\end{array}$ & $\begin{array}{c}P \\
(\mathrm{ppm})\end{array}$ & $\begin{array}{c}\text { Zeleny Volume } \\
(\mathrm{mL})\end{array}$ & $\mathbf{b}^{*}$ \\
\hline 1 & 12 & $4.31 \mathrm{i}$ & $12.49 \mathrm{~h}$ & $69.99 \mathrm{a}$ & $491.59 \mathrm{f}$ & $12.73 \mathrm{f}$ & $33.60 \mathrm{de}$ & $46.40 \mathrm{bc}$ & $660.80 \mathrm{k}$ & $13.80 \mathrm{a}$ & $13.02 \mathrm{~b}$ \\
\hline 2 & 2 & $7.27 \mathrm{~b}$ & $14.63 \mathrm{~d}$ & $65.29 \mathrm{efg}$ & $567.35 \mathrm{ab}$ & $27.72 \mathrm{a}$ & $32.00 \mathrm{de}$ & $48.00 \mathrm{abc}$ & $2059.20 \mathrm{~h}$ & $10.80 \mathrm{ab}$ & $13.69 \mathrm{ab}$ \\
\hline 3 & 3 & $5.59 \mathrm{~h}$ & $14.69 \mathrm{~d}$ & 66.55 cde & $553.48 \mathrm{~cd}$ & $23.21 \mathrm{bcd}$ & $44.80 \mathrm{ab}$ & $57.60 \mathrm{a}$ & $4630.40 \mathrm{c}$ & $10.30 \mathrm{ab}$ & $18.11 \mathrm{ab}$ \\
\hline 4 & 8 & $7.10 \mathrm{c}$ & $15.17 \mathrm{~b}$ & $64.64 \mathrm{fg}$ & 544.34 de & $20.43 \mathrm{~d}$ & $48.00 \mathrm{a}$ & $57.60 \mathrm{a}$ & $6419.20 \mathrm{a}$ & $9.30 \mathrm{~b}$ & $16.42 a b$ \\
\hline 5 & 7 & $5.59 \mathrm{~h}$ & $14.26 \mathrm{e}$ & $67.03 \mathrm{~cd}$ & $540.18 \mathrm{e}$ & $20.20 \mathrm{~d}$ & $30.40 \mathrm{e}$ & $52.80 \mathrm{ab}$ & $206.40 \mathrm{~m}$ & $11.30 \mathrm{ab}$ & $15.53 \mathrm{ab}$ \\
\hline 6 & 4 & $4.38 \mathrm{i}$ & $13.76 \mathrm{f}$ & $68.93 \mathrm{ab}$ & $575.95 \mathrm{a}$ & $22.07 \mathrm{~cd}$ & $46.40 \mathrm{a}$ & $33.60 \mathrm{~d}$ & $1889.60 \mathrm{i}$ & $11.30 \mathrm{ab}$ & $15.00 \mathrm{ab}$ \\
\hline 7 & 13 & $8.98 \mathrm{a}$ & $15.11 b c$ & $63.89 \mathrm{~g}$ & $537.07 \mathrm{e}$ & $24.17 \mathrm{abcd}$ & $40.00 \mathrm{bc}$ & $51.20 \mathrm{abc}$ & $4636.80 \mathrm{~b}$ & $10.55 \mathrm{ab}$ & $15.13 \mathrm{ab}$ \\
\hline 9 & 11 & $6.11 \mathrm{f}$ & $15.04 \mathrm{c}$ & $65.58 \mathrm{defg}$ & 560.44 bc & $25.11 \mathrm{abc}$ & $44.80 \mathrm{ab}$ & $46.40 \mathrm{bc}$ & $2262.40 \mathrm{~g}$ & $10.55 \mathrm{ab}$ & $18.23 \mathrm{ab}$ \\
\hline 10 & 10 & $5.62 \mathrm{~h}$ & $14.24 \mathrm{e}$ & $67.04 \mathrm{~cd}$ & 544.99 de & $23.49 \mathrm{bcd}$ & $36.80 \mathrm{~cd}$ & $43.20 \mathrm{~cd}$ & $1763.20 \mathrm{j}$ & $11.80 \mathrm{ab}$ & $16.24 \mathrm{ab}$ \\
\hline 11 & 6 & $5.79 \mathrm{~g}$ & $13.43 \mathrm{~g}$ & $67.36 \mathrm{bc}$ & 561.85 bc & $26.22 \mathrm{ab}$ & $36.80 \mathrm{~cd}$ & $48.00 \mathrm{abc}$ & 459.201 & $10.80 \mathrm{ab}$ & $17.24 \mathrm{ab}$ \\
\hline 12 & 9 & $6.09 \mathrm{f}$ & $13.71 \mathrm{f}$ & 66.14 cdef & $560.96 \mathrm{bc}$ & $23.89 \mathrm{abcd}$ & $44.80 \mathrm{ab}$ & $48.00 \mathrm{abc}$ & $3299.20 \mathrm{e}$ & $10.55 \mathrm{ab}$ & $19.50 \mathrm{a}$ \\
\hline 13 & 1 & $6.68 \mathrm{~d}$ & $15.20 \mathrm{~b}$ & $64.51 \mathrm{fg}$ & $563.01 \mathrm{abc}$ & $23.67 \mathrm{abcd}$ & $44.80 \mathrm{ab}$ & $49.60 \mathrm{abc}$ & $3372.80 \mathrm{~d}$ & $10.30 \mathrm{ab}$ & $18.50 \mathrm{ab}$ \\
\hline
\end{tabular}

Means with different letters within the same column are significantly different according to Duncan's test $(p<0.05)$. DM: Dry Matter; GAE: Gallic Acid Equivalent. 

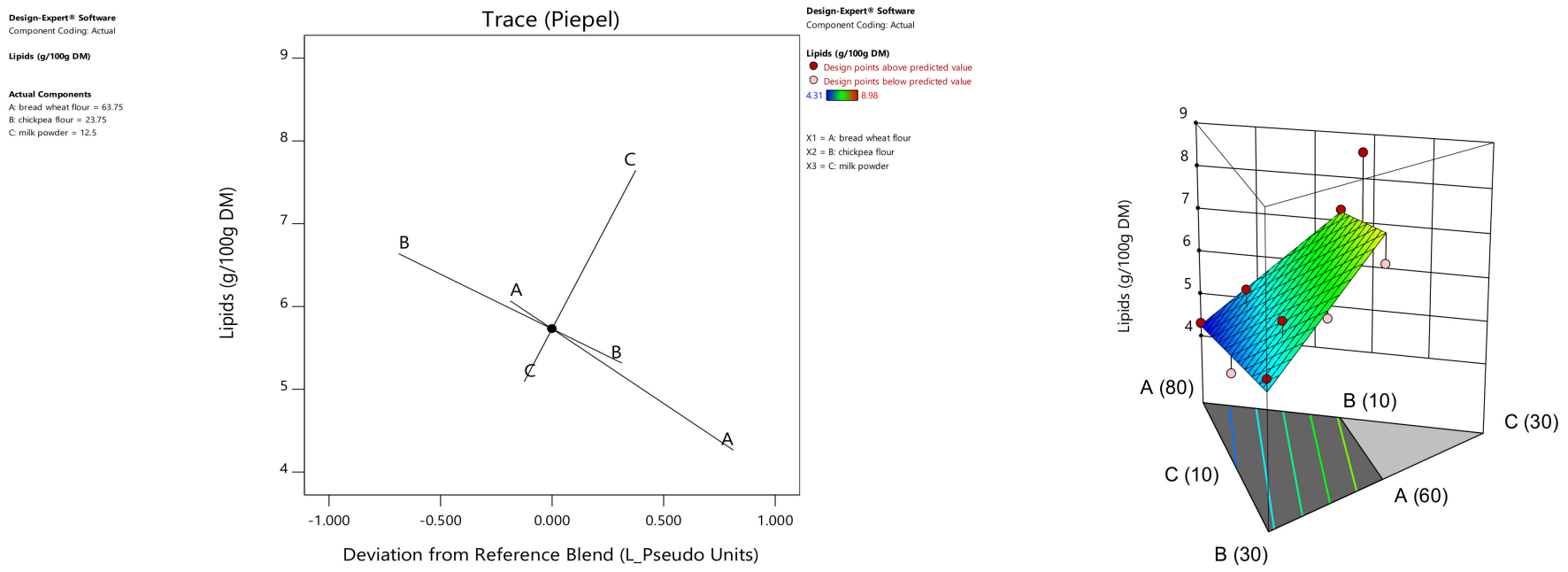

(a)

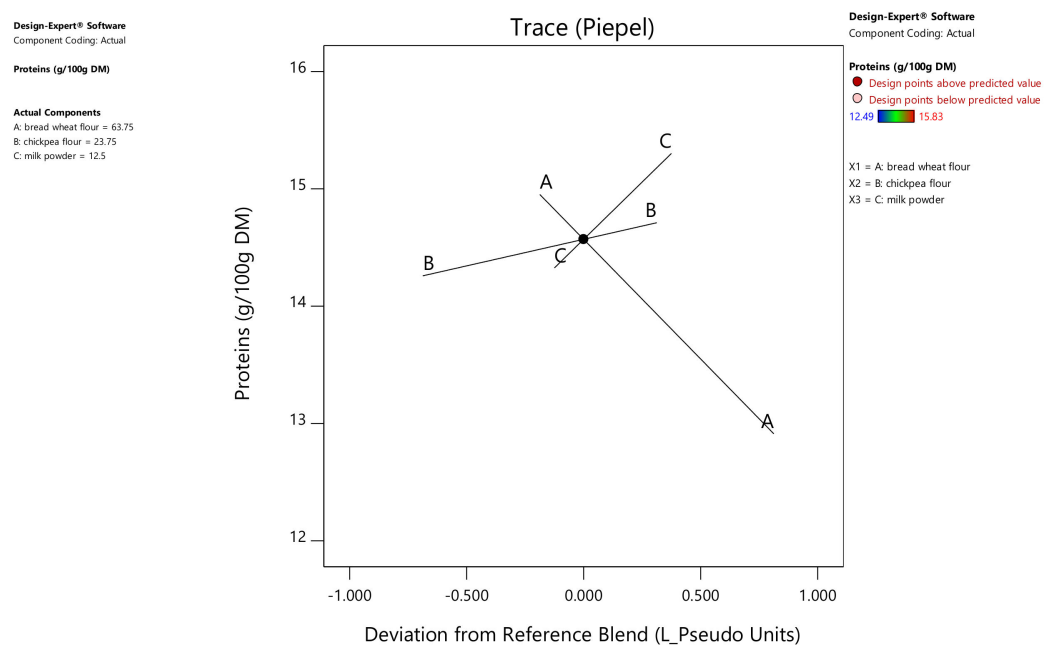

(b)

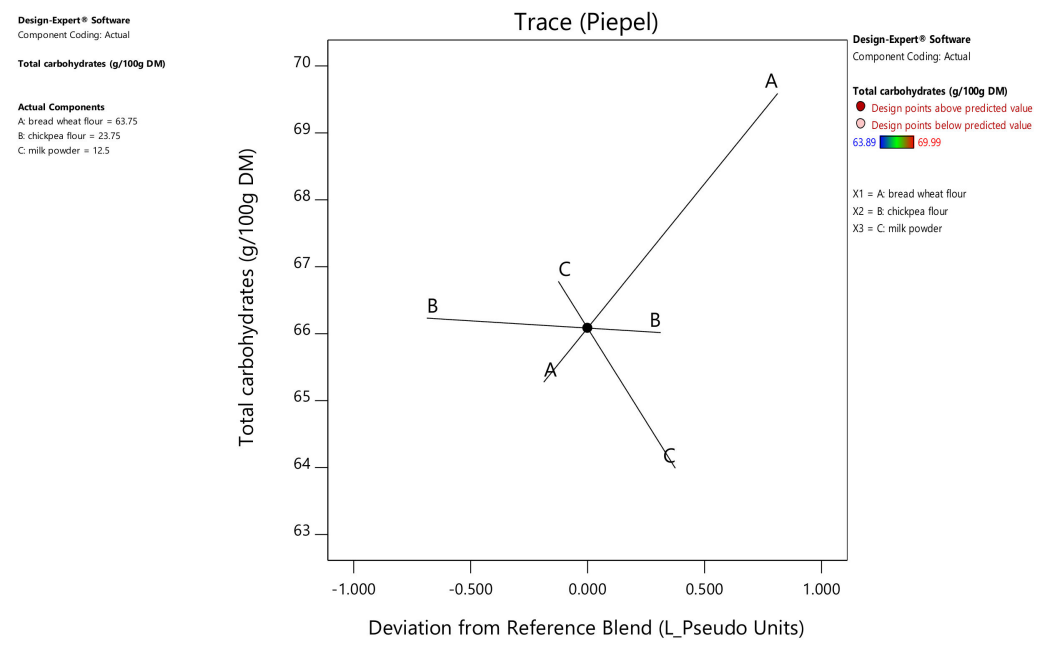

(c)

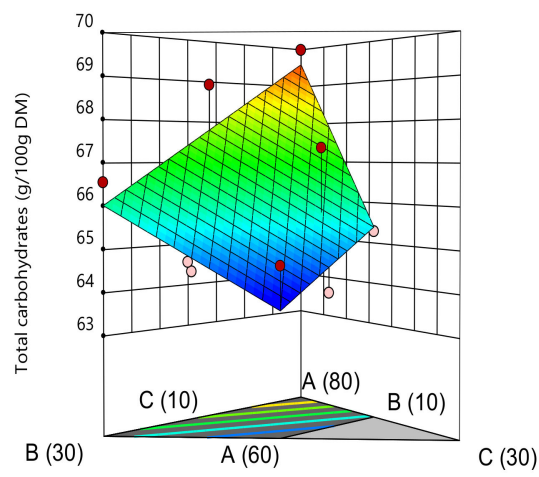

Figure 1. Trace plot curves and response surface (2D and 3D) presentations of lipid (a), protein (b), and total carbohydrate (c) variations in flour blends (A: Bread wheat, B: Chickpea, C: Milk powder). 


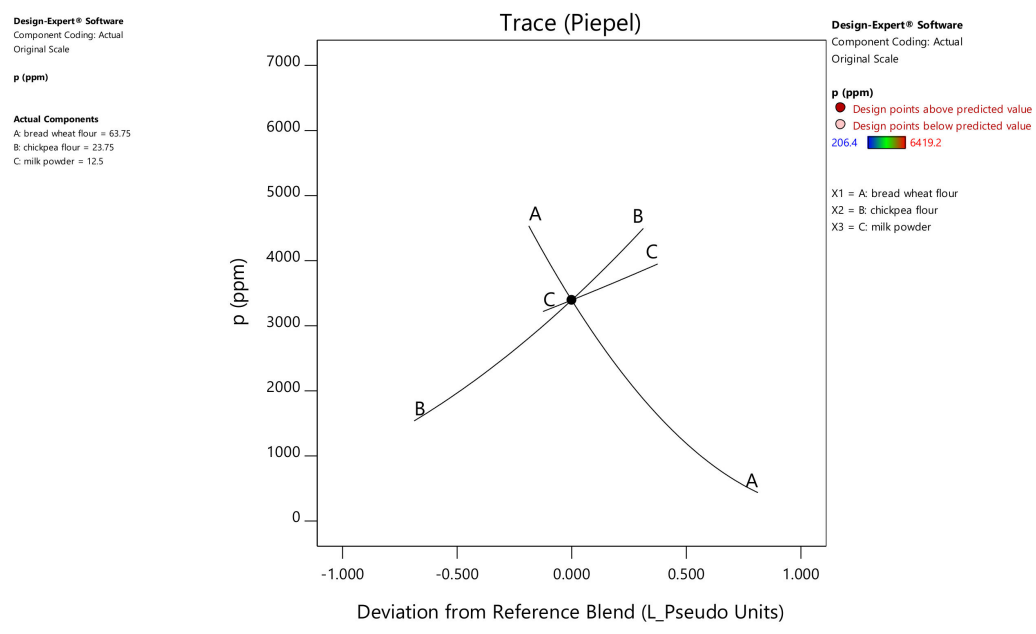

(a)

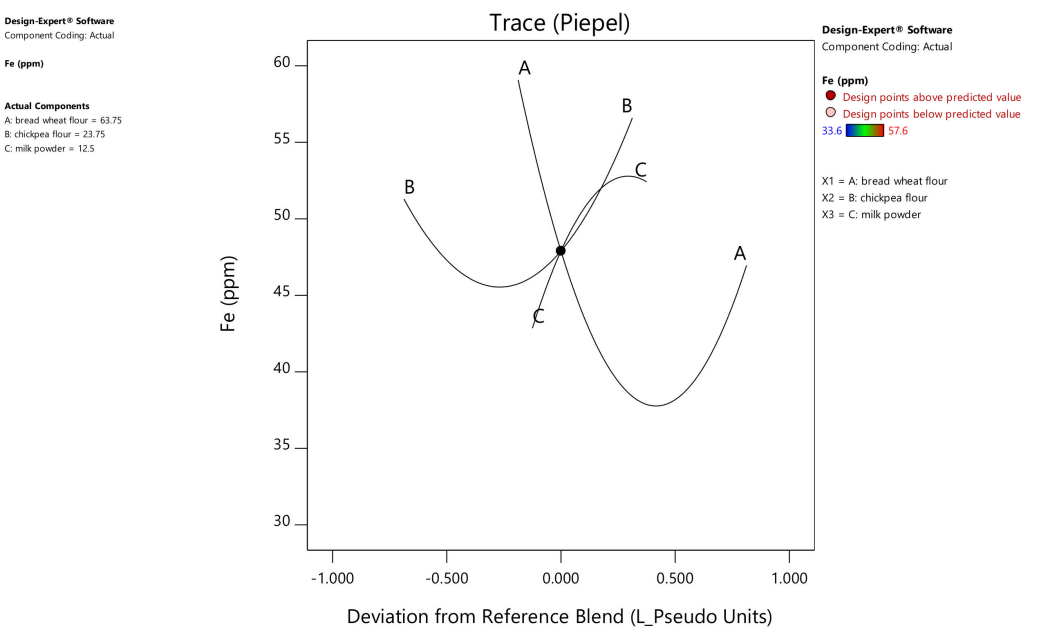

(b)

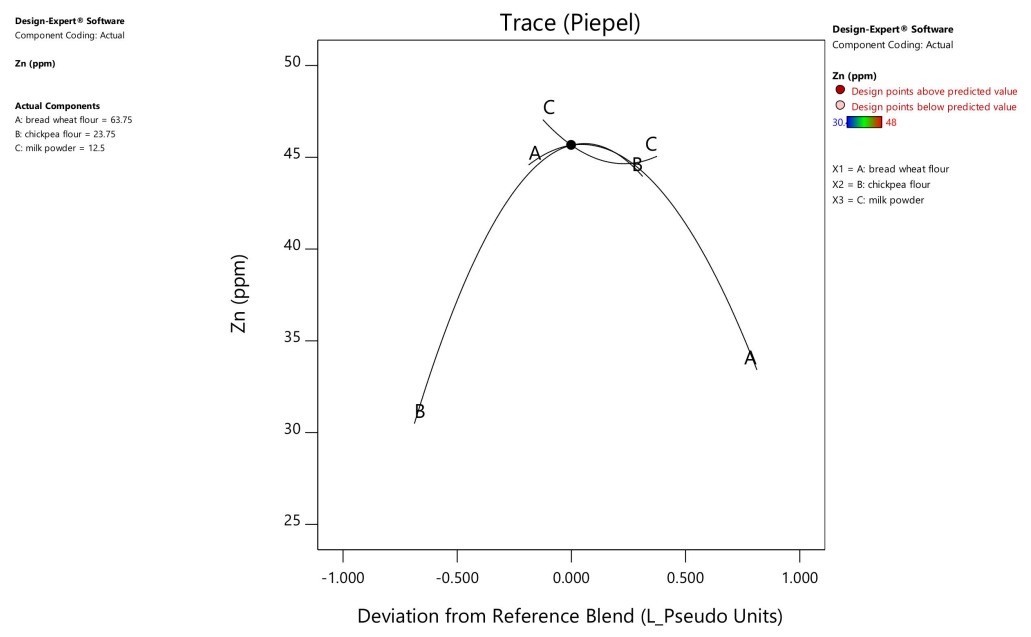

(c)
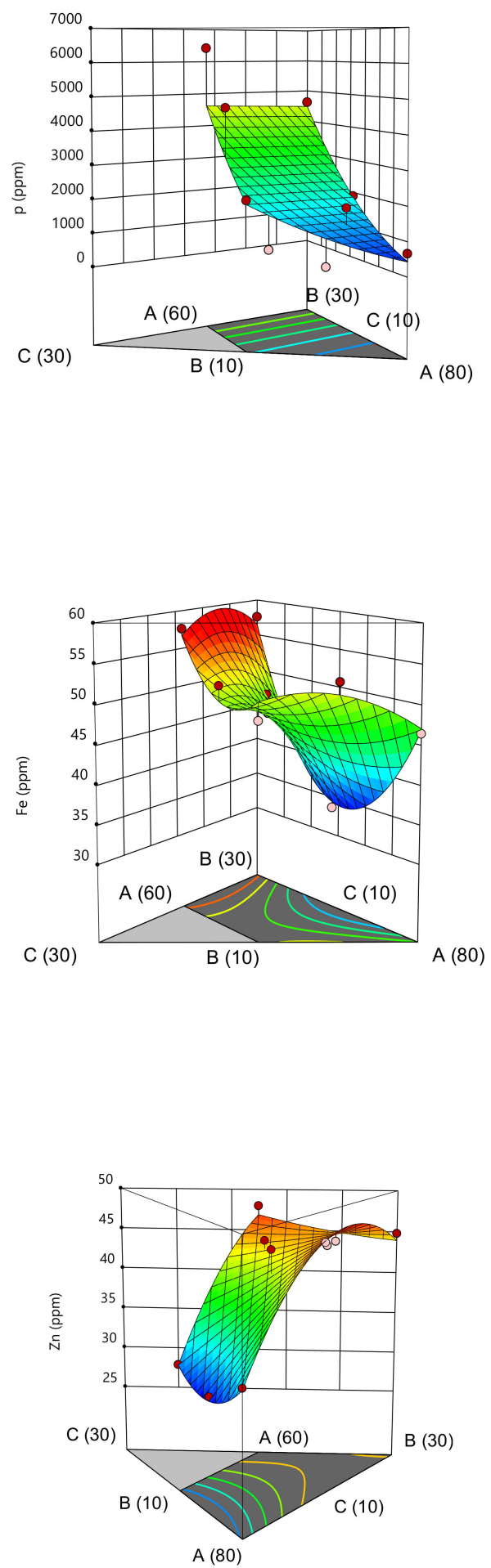

Figure 2. Trace plot curves and response surface (2D and 3D) presentations of phosphorus (a), iron (b), and zinc (c) variation in flour blends (A: Bread wheat, B: Chickpea, C: Milk powder). 

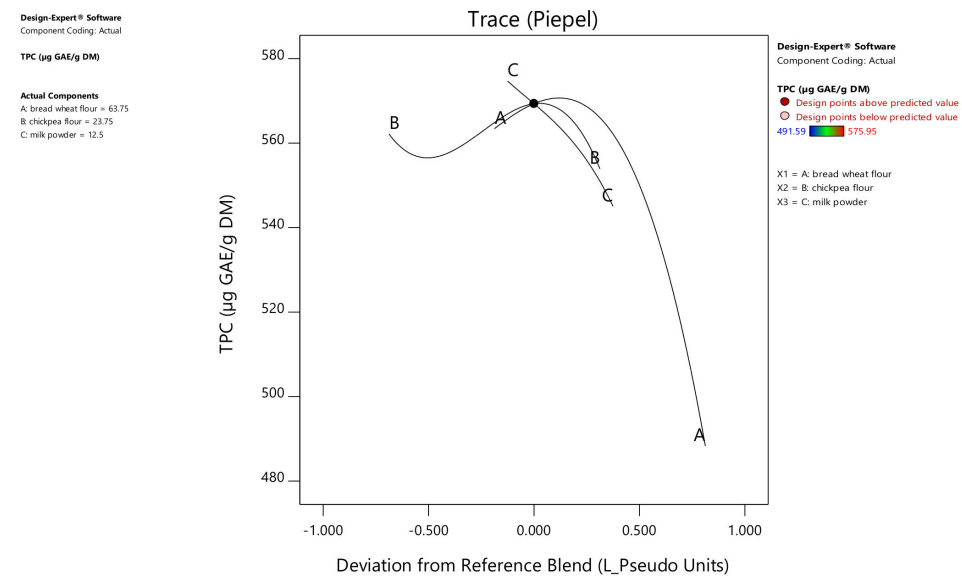

(a)
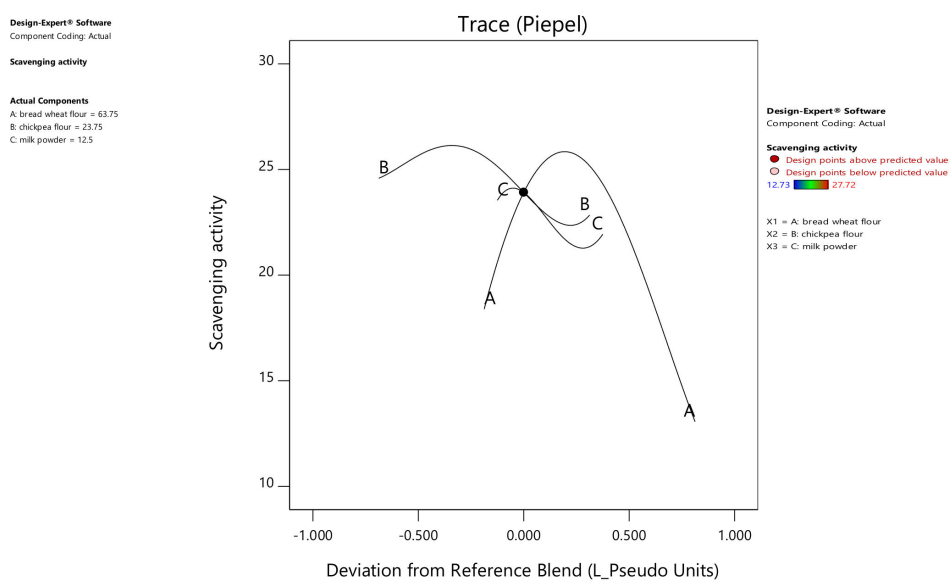

(b)
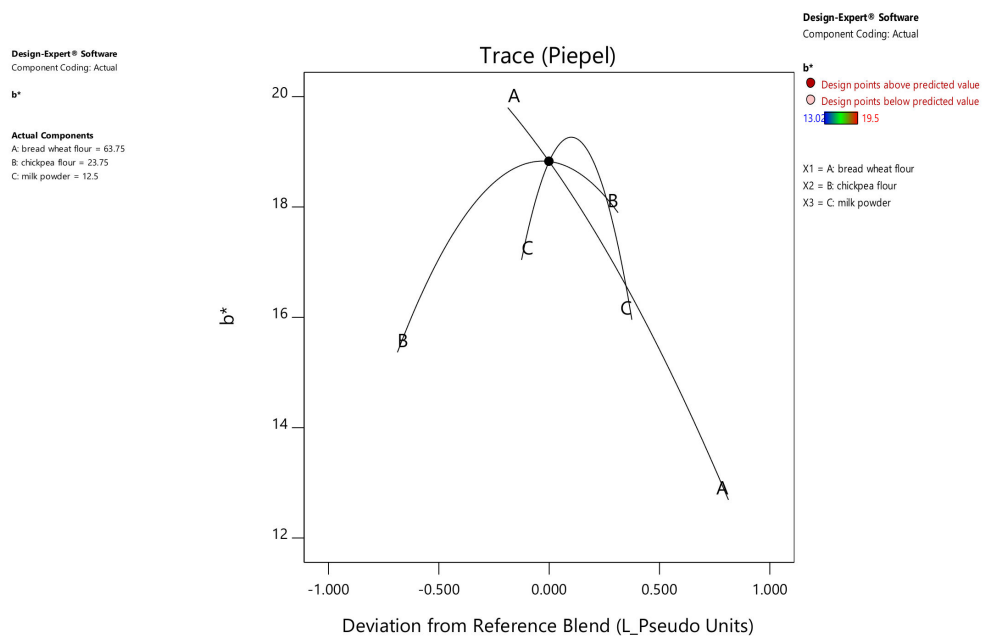

(c)
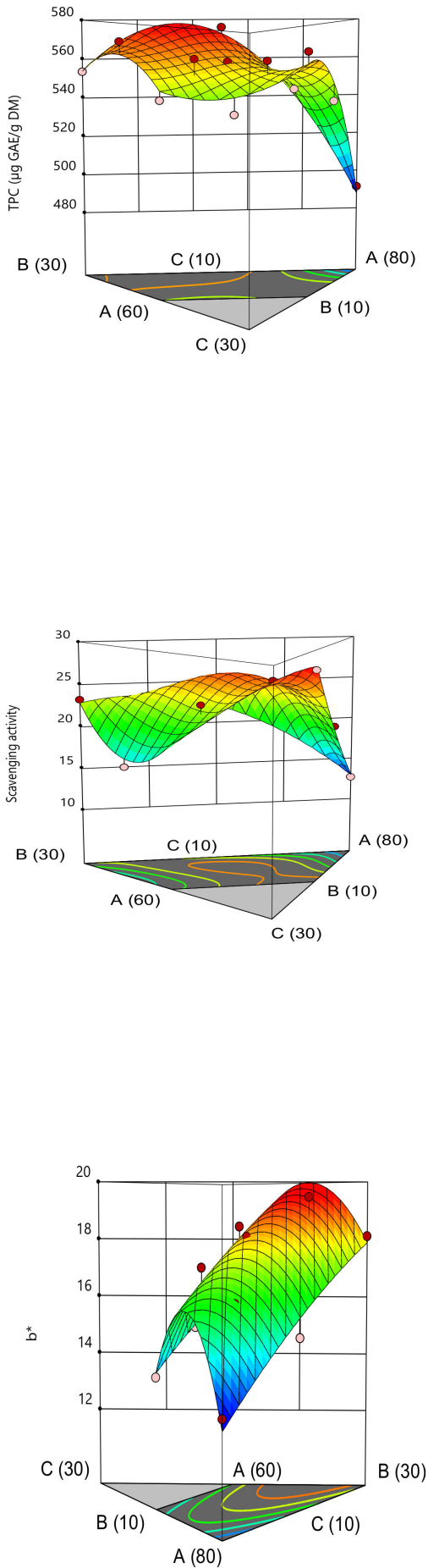

Figure 3. Cont. 

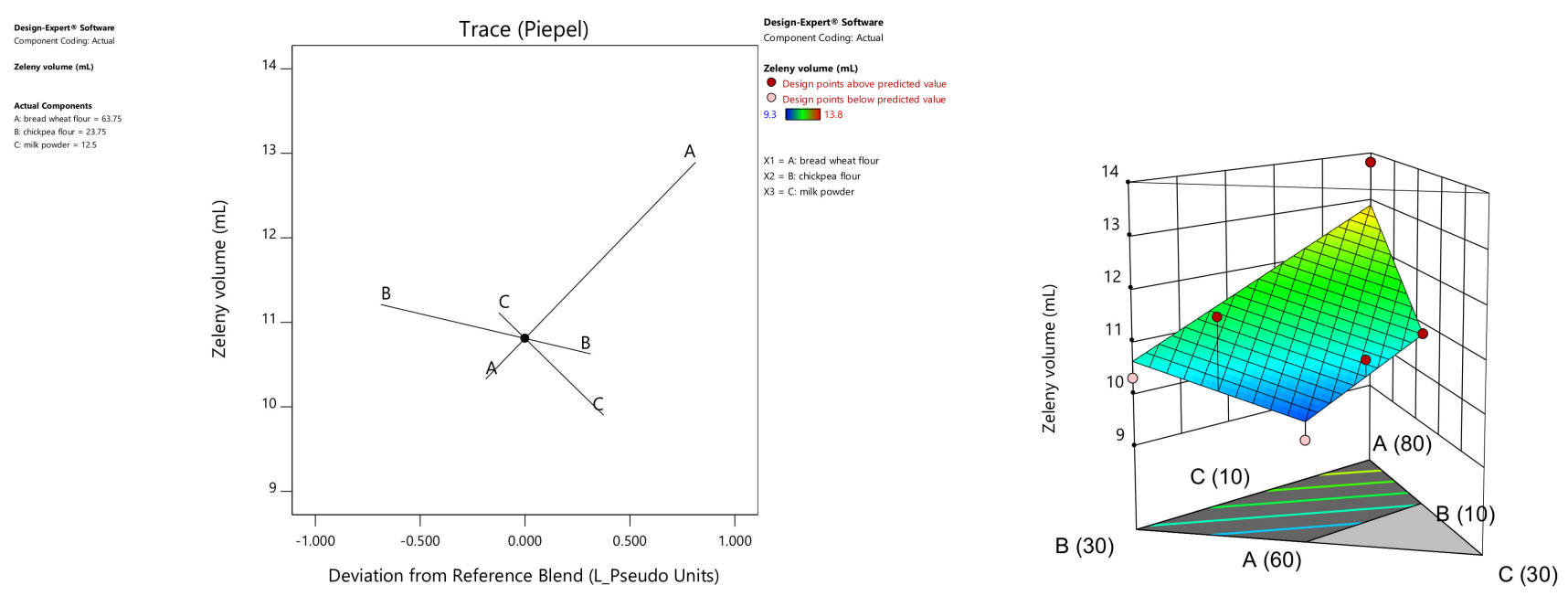

(d)

Figure 3. Trace plot curves and response surface (2D and 3D) presentations of total phenolic content (a), scavenging activity (b), zeleny volume (c), and yellow index (d) variation in flour blends (A: Bread Wheat, B: Chickpea, C: Milk powder).

Concerning the scavenging activity, the validated model was special quartic $(p=0.0057)$, and the scavenging activity ranged from 12.73 to $27.72 \%$. Milk powder and chickpea flour positively influenced this response in bread wheat flour through significant terms $(B, C$, $\mathrm{AB}$, and $\left.\mathrm{A}^{2} \mathrm{BC}\right)$. This might be due to the chickpea content in terms of the polyphenols. Earlier studies undertaken on dough and pasta revealed that products made with wheat flour fortified with chickpea exhibited a higher polyphenol content and antioxidant activity, eventually doubling the control content [43]. The positive effect of milk powder on scavenging activity may be due to the natural milk antioxidants or due to the industrial supplementation of these molecules [44].

\subsection{Technological Quality of Flour Mixture}

The regression equation of the zeleny volume was of a linear order $(p=0.002)$ and was positively influenced by the addition of wheat flour. This makes sense given the nature of the added ingredients. The addition of chickpea flour and milk powder caused the dilution of the gluten provided by wheat flour (Figure 3). Bojnanská and Urminská [45] also reported a lower zeleny value with the addition of natural gluten free ingredients in wheat flour.

Concerning the yellow index, the regression equation was of a quadratic order $(p=0.0002)$ (Table 1), where the chickpea ratio had the most significant effect on increasing this parameter among the linear terms that were succeeded by wheat flour, while milk powder had a diluting effect. Binary terms (AC and $B C$ ) indicated a positive interaction on the yellow index. These results are in agreement with the results of Yıldırım and Karaboğa [46], who demonstrated that the addition of chickpea flour to bread wheat flour increased the yellow index $\left(b^{*}\right)$.

\subsection{Blend Optimization}

The optimization of the flour mixtures was based on the mathematical equation of Derringer and Suich [34]. This operation consisted of looking for the concomitant graphical and numerical optimum involving the addressed answers for the nutritional (proteins, lipids, carbohydrates, Fe, Zn, P, polyphenols, and scavenging activity) and technological (zeleny volume, yellow index) levels. The ingredients were set as independent factors by maximizing the level of incorporated chickpea flour and minimizing the level of bread wheat flour and milk powder (Figure S1). According to the numerical optimization, the optimal point corresponded to the mixture composed of $60 \%$ bread wheat flour, $23.8 \%$ chickpea flour, and $16.2 \%$ milk powder. The graphical optimization of the mixture re- 
vealed the same proportions obtained by the numerical optimization, corresponding to a desirability of 0.77 (Table S1).

\subsection{Farinograph Test}

The optimization of the nutritional quality of the dough by replacing part of the bread wheat flour with chickpea flour and milk powder brought slight modifications in the farinograph results (Table 3). Water absorption did not differ between the control (bread wheat dough) and the optimal blend dough, even if the proportion of chickpea flour reached $26 \%$ in the flour mixture. These results are contrary to the results of Mohammed et al. [14], which showed that the water absorption of the dough steadily increased with addition of chickpea flour from 10 to $30 \%$. This discordance can be explained by the potential functional interaction between the milk powder and the chickpea proteins and gluten. Indeed, by its protein and pentosan content, chickpea flour grants a high water absorption capacity to dough [47]. In parallel, milk powder has a distinct tendency for water absorption compared to wheat flour [48]. In fact, milk proteins decrease water absorption in dough [49]. These different behaviors probably affected the protein matrix of the blend when the three ingredients were together, and thus maintained the water absorption at the same level as that of the control. This parameter is considered as an important factor in commercial bread dough production, for controlling dough handling, proofing, and baking and sensorial characteristics are necessary to produce desired baked foods such as bread [50].

Table 3. Farinograph parameters of the optimal composite flour dough.

\begin{tabular}{cccccc}
\hline Treatments & $\begin{array}{c}\text { Dough } \\
\text { Development Time } \\
\text { mn:ss }\end{array}$ & $\begin{array}{c}\text { Consistancy } \\
\text { BU }\end{array}$ & $\begin{array}{c}\text { Water } \\
\text { Absorption } \\
\text { \% }\end{array}$ & $\begin{array}{c}\text { Stability } \\
\text { mn:ss }\end{array}$ & $\begin{array}{c}\text { Softening } \\
\text { Degree } \\
\text { BU }\end{array}$ \\
\hline Control(bread wheat dough) & $1: 07 \mathrm{a}$ & 553 & 51.8 & $1: 09$ & $82 \mathrm{a}$ \\
Optimized blend dough & $1: 55 \mathrm{~b}$ & 527 & 59.0 & $1: 44$ & $\mathrm{~ns}$ \\
Probability & 0.01 & $\mathrm{~ns}$ & $\mathrm{~ns}$ & 0.05 & $\mathrm{~ns}$ \\
\hline
\end{tabular}

Values with different letters are significantly different at $p \leq 0.01$ or $p \leq 0.05$; ns are not significantly different. BU: Brabender Unit; mn: minute; ss: seconds.

Regarding development time, the time required to reach the consistency of $500 \mathrm{BU}$ for the optimal dough was significantly $(p<0.01)$ higher than that of the control (Table 3$)$. This might be attributed to the milk caseins [19].

The optimal blend showed a significantly $(p<0.05)$ lower softening degree in comparison to the control dough. When chickpea was used alone, its proportion linearly increased the softening degree [14]. Dough stability remained unchanged between the control and the optimized flour doughs (Table 3). However, it decreased consistently when chickpea flour was used alone, with increased levels in wheat bread fortification due to the dilution and interference executed by the fibers provided by the chickpea flour on the gluten network [14,47,51]. The findings of Kenny et al. [19], Madenci and Bilgiçli [41], and Alsuhaibani [42] also indicated that the addition of milk whey protein concentrates, butter proteins, and milk improved dough properties in terms of stability. This parameter might also be improved by the high calcium content of milk powder, as the addition of salt has shown a positive effect on dough stability [52].

Analysis of the farinograph parameters predicted that the optimal flour blend of bread wheat, chickpea, and milk powder in a 60:24:16 ratio preserved approximately the same bread-making quality of the control wheat flour. Even if there was small difference in terms of development time, the hydration capacity and stability remained unchanged. The decreased softening degree demonstrated support to the gluten network during kneading, which is mainly due to the rheological role played by the milk powder, which has demonstrated the ability to enhance the overall physical properties of wheat pan bread [40], fighting the worsening bread-making attitude brought by chickpea on wheat flour [47]. 
The functional improvement brought by milk powder to the wheat and chickpea flour blend could be compared to the gluten effect on the same matrix tested by Singh et al. [51]. The addition of gluten at a 3\% level was found to effectively improve the rheological characteristics of wheat-chickpea flour blends with the maximum addition level of $20 \%$. This proved that we managed to obtain a nutritionally optimized mixture with good baking quality $[14,53]$ without the use of gluten.

\subsection{Sensory Profile of Optimized Bread}

The sensory acceptance of the formulated breads on the basis of the scores given by the panelists (Table 4, Figure S2) showed no significant difference between the optimal and control bread with regard to crumb and chewiness. However, appearance, crust, aroma, and the taste of the bread formulated with the optimal flour blend scored higher appreciation (Photo S1).

Table 4. Sensory quality scores of optimized blend bread compared to wheat bread (control).

\begin{tabular}{ccccccc}
\hline & \multicolumn{7}{c}{ Sensory Quality Scores } \\
& Appearance & Crust & Crumb & Chewiness & Aroma & Taste \\
\hline Optimized blend bread & $7.6 \mathrm{a}$ & $7.8 \mathrm{a}$ & 6.9 & 7.2 & $7.5 \mathrm{a}$ & $7.7 \mathrm{a}$ \\
Control (100\%Bread wheat) & $6.1 \mathrm{~b}$ & $6.7 \mathrm{~b}$ & 7.0 & 7.3 & $6.2 \mathrm{~b}$ & $6.4 \mathrm{~b}$ \\
Probability & 0.01 & 0.01 & $\mathrm{~ns}$ & $\mathrm{~ns}$ & 0.05 & 0.01 \\
\hline
\end{tabular}

Values with a different letter within the same column are significantly different at $p \leq 0.01$ or $p \leq 0.05$ as indicated; ns values are not significantly different. Each value is an average of 30 replications.

These results suggest that in addition to the nutritional and rheological improvement brought to the flour and dough of the mixture (bread wheat-chickpea-milk powder), the bread made with the optimal blend gained the confidence and acceptability of the interviewed panel. This improvement in sensory quality may be due to the conjugated action of the milk powder and chickpea flour. The milk powder enhanced the crust and crumb softness [54] and thus corrected the negative action of the high chickpea ratio (26\%) on these characteristics. Singh et al. [51] demonstrated that the softness of chapati, an Indian pancake, deteriorated with the increase of a chickpea flour level beyond $20 \%$. In another study by Yamsaengsung et al. [55], crumb softness could not be obtained in bread made from chickpea flour, and despite the use of water and emulsifier, the latter did not correlate positively with the alveoli improvement brought by these two elements.

Due to its functional properties, milk powder upgraded dough viscoelastic development and thus improved the softness of the crumb, confirming the results obtained by Sanchez et al. [56]. Indeed, Sharma et al. [57] revealed that whey proteins had good emulsifying properties and contributed to the correct distribution of fat in the dough, thus ensuring crumb softness.

The aroma and taste of the optimal blend bread were better than those of the control bread. This may be due to the action of the chickpea flour, which, as reported earlier by Miñarro et al. [58], indicates that good sensory behavior could be achieved with the addition of chickpea flour, and it could be a substitute to soya protein in bread making.

Crust improvement was expressed by the specific color development in the optimal blend bread. The darkness and yellowness of bread increased, and this might be attributed to the milk solids, which are useful color contributors due to the Maillard reaction, the products of which positively influence the flavor of bread [59]. This reaction was also favored by the high lysine content of the chickpea powder [14].

\section{Conclusions}

The present study, conducted through the mixture design methodology, obtained an optimal nutritional mixture based on $60 \%$ bread wheat, $24 \%$ chickpea flour, and $16 \%$ milk powder. The milk powder not only boosted the nutritional potential of the mixture, but it also improved the overall bread making quality of the chickpea-bread wheat mixture in comparison to that of wheat bread by enhancing its rheological and sensorial qualities 
in regard to chewiness and crumb, which remained unchanged and thus overcame the technological inconvenience of the addition of chickpea flour. This opens the way for future in-depth research on the effect of milk fractions (caseins, whey, etc.,) on the nutritional and rheological quality of cereal-legume composite flours as well as the behavior of milk proteins in this matrix.

Supplementary Materials: The following are available online at https: / www.mdpi.com/article / 10.3390/foods10081843/s1, Figure S1: Response surface mixture optimization of composite flour, Figure S2: Average acceptance for optimized and control breads, Table S1: Graphical and numerical optimization of composite flour, Photo S1: Formulated breads: from left a)-optimized bread, b)-bread wheat bread (control).

Author Contributions: Conceptualization, A.B., S.K. and M.O.; methodology, A.B., M.T., Y.E.-n. and N.B.; software, F.G.; formal analysis, A.B., Y.N., A.E. and M.R.K.; investigation, A.B., Y.N., A.E. and M.R.K.; resources, E.H.E.M.; data curation, F.G.; writing-original draft preparation, A.B., S.K. and M.O.; writing-review and editing, A.B., Y.N., M.T., E.H.E.M., S.K. and M.O.; supervision, S.K. and M.O.; project administration, E.H.E.M.; funding acquisition, S.K. All authors have read and agreed to the published version of the manuscript.

Funding: This research was financed by the fellowship for enhancing the Capacity of Young Arab Scientists in Agricultural Research for Development from the Arab Fund for Economic and Social development (AFESD) and by the CGIAR Research Program on Grain Legumes and Dryland Cereals (GLDC), ICARDA.

Acknowledgments: The authors extend special thanks to the International Center for Agricultural Research in the Dry Areas (ICARDA) and the National Institute of Agricultural Research (INRA) for their support in the execution of this research and especially for the use of the laboratory facilities and for the scientific supervision.

Conflicts of Interest: The authors declare no conflict of interest. The funders had no role in the design of the study; in the collection, analyses, or interpretation of data; in the writing of the manuscript, or in the decision to publish the results.

\section{References}

1. Bassett, C.; Boye, J.; Tyler, R.; Oomah, B.D. Molecular, functional and processing characteristics of whole pulses and pulse fractions and their emerging food and nutraceutical applications. Food Res. Int. 2010, 43, 2268. [CrossRef]

2. Jain, A.K.; Kumar, S.; Panwar, J.D.S. Antinutritional factors and their detoxification in pulses-a review. Energy (K Cal) 2009, 139, 90-94.

3. Tosh, S.M.; Yada, S. Dietary fibres in pulse seeds and fractions: Characterization, functional attributes, and applications. Food Res. Int. 2010, 43, 450-460. [CrossRef]

4. Leterme, P. Recommendations by health organizations for pulse consumption. Br. J. Nutr. 2002, 88, 239-242. [CrossRef] [PubMed]

5. Lal, R. Improving soil health and human protein nutrition by pulses-based cropping systems. Adv. Agron. 2017, 145, 167-204.

6. Tsao, R.; Shahidi, F. Commemoration of the International Year of Pulses 2017; Elsevier: Amsterdam, The Netherlands, 2017.

7. Abu-Ghannam, N.; Gowen, A. Pulse-based food products. Pulse Foods Process. Qual. Nutraceutical Appl. 2011, 141, $249-278$.

8. Rizzello, C.G.; Coda, R.; Gobbetti, M. Use of sourdough fermentation and nonwheat flours for enhancing nutritional and healthy properties of wheat-based foods. In Fermented Foods in Health and Disease Prevention; Elsevier: Amsterdam, The Netherlands, 2017; pp. $433-452$.

9. Jukanti, A.K.; Gaur, P.M.; Gowda, C.L.L.; Chibbar, R.N. Nutritional quality and health benefits of chickpea (Cicer arietinum L.): A review. Br. J. Nutr. 2012, 108, S11-S26. [CrossRef] [PubMed]

10. De Camargo, A.C.; Favero, B.T.; Morzelle, M.C.; Franchin, M.; Alvarez-Parrilla, E.; de la Rosa, L.A.; Geraldi, M.V.; Marostica Junior, M.R.; Shahidi, F.; Schwember, A.R. Is chickpea a potential substitute for soybean? Phenolic bioactives and potential health benefits. Int. J. Mol. Sci. 2019, 20, 2644. [CrossRef] [PubMed]

11. Kalefetoğlu, T.; Macar, O.; Dürdane, İ. Variability in some biochemical and nutritional characteristics in desi and Turkish kabuli chickpea (Cicer arietinum L.) types. Celal Bayar Üniversitesi Fen Bilim. Derg. 2017, 13, 677-680. [CrossRef]

12. Dalgetty, D.D.; Baik, B. Fortification of bread with hulls and cotyledon fibers isolated from peas, lentils, and chickpeas. Cereal Chem. 2006, 83, 269-274. [CrossRef]

13. Man, S.; Păucean, A.; Muste, S.; Pop, A. Effect of the chickpea (Cicer arietinum L.) flour addition on physicochemical properties of wheat bread. Bull. UASVM Food Sci. Technol. 2015, 72, 41-49. [CrossRef]

14. Mohammed, I.; Ahmed, A.R.; Senge, B. Dough rheology and bread quality of wheat-chickpea flour blends. Ind. Crop. Prod. 2012, 36, 196-202. [CrossRef] 
15. Mohammed, I.; Ahmed, A.R.; Senge, B. Effects of chickpea flour on wheat pasting properties and bread making quality. J. Food Sci. Technol. 2014, 51, 1902-1910. [CrossRef] [PubMed]

16. Don, C.; Lichtendonk, W.J.; Plijter, J.J.; Hamer, R.J. Understanding the link between GMP and dough: From glutenin particles in flour towards developed dough. J. Cereal Sci. 2003, 38, 157-165. [CrossRef]

17. Goesaert, H.; Brijs, K.; Veraverbeke, W.S.; Courtin, C.M.; Gebruers, K.; Delcour, J.A. Wheat flour constituents: How they impact bread quality, and how to impact their functionality. Trends Food Sci. Technol. 2005, 16, 12-30. [CrossRef]

18. Mayorga, B.O.; Gómez, M. Dairy Ingredients. Bakery Products Science and Technology; Zhou, W., Ed.; Wiley Blackwell: West Sussex, UK, 2014; p. 259.

19. Kenny, S.; Wehrle, K.; Stanton, C.; Arendt, E.K. Incorporation of dairy ingredients into wheat bread: Effects on dough rheology and bread quality. Eur. Food Res. Technol. 2000, 210, 391-396. [CrossRef]

20. Moore, M.M.; Schober, T.J.; Dockery, P.; Arendt, E.K. Textural comparisons of gluten-free and wheat-based doughs, batters, and breads. Cereal Chem. 2004, 81, 567-575. [CrossRef]

21. Arendt, E.; Dal Bello, F. Gluten-Free Cereal Products and Beverages; Elsevier: Amsterdam, The Netherlands, 2011 ; ISBN 0080557767.

22. Mathieu, D.; Phan-Tan-Luu, R.; Sergent, M. Criblage et étude des facteurs. LPRAI Marseille 1996.

23. Buruk Sahin, Y.; Aktar Demirtaş, E.; Burnak, N. Mixture Design: A Review of Recent Applications in the Food Industry. Pamukkale Univ. J. Eng. Sci. 2016, 22, 297-304. [CrossRef]

24. Akande, A.; Jolayemi, O.S.; Familusi, A.; Idowu, B. Nutritional, antioxidant and sensory properties of rice-based masa enriched with grain amaranth and carrot powder. Ann. Food Sci. Technol. 2018, 19, 645-656.

25. Kayacier, A.; Yüksel, F.; Karaman, S. Simplex Lattice Mixture Design Approach on Physicochemical and Sensory Properties of Wheat Chips Enriched with Different Legume Flours: An Optimization Study Based on Sensory Properties. LWT-Food Sci. Technol. 2014, 58, 639-648. [CrossRef]

26. Yuksel, F.; Campanella, O.H. Textural, Rheological and Pasting Properties of Dough Enriched with Einkorn, Cranberry Bean and Potato Flours, Using Simplex Lattice Mixture Design. Qual. Assur. Saf. Crop. Foods 2018, 10, 389-398. [CrossRef]

27. Yilmaz, M.T.; Yildiz, Ö.; Yurt, B.; Toker, O.S.; Karaman, S.; Baştürk, A. A Mixture Design Study to Determine Interaction Effects of Wheat, Buckwheat, and Rice Flours in an Aqueous Model System. LWT-Food Sci. Technol. 2015, 61, 583-589. [CrossRef]

28. AOAC. Official Methods of Analysis of the Association of Official Analytical Chemists International 2000, 17th ed.; AOAC International: Gaithersburg, MD, USA, 2000.

29. Thavarajah, D.; Thavarajah, P.; Sarker, A.; Vandenberg, A. Lentils (Lens culinaris medikus subspecies culinaris): A whole food for increased iron and zinc intake. J. Agric. Food Chem. 2009, 57, 5413-5419. [CrossRef]

30. Alcock, N.W. A hydrogen-peroxide digestion system for tissue trace-metal analysis. Biol. Trace Elem. Res. 1987, 13, 363-370. [CrossRef] [PubMed]

31. Singleton, V.L.; Rossi, J.A. Colorimetry of total phenolics with phosphomolybdic-phosphotungstic acid reagents. Am. J. Enol. Vitic. 1965, 16, 144-158.

32. Brand-Williams, W.; Cuvelier, M.-E.; Berset, C. Use of a free radical method to evaluate antioxidant activity. LWT-Food Sci. Technol. 1995, 28, 25-30. [CrossRef]

33. International Organization for Standardization. ISO 5529:2007 Wheat-Determination of the Sedimentation Index-Zeleny Test; International Organization for Standardization: Geneva, Switzerland, 2007.

34. Derringer, G.; Suich, R. Simultaneous optimization of several response variables. J. Qual. Technol. 1980, 12, 214-219. [CrossRef]

35. AACC. Approved Methods of the American Association of Cereal Chemists, 10th ed.; Cereals \& Grains Assn: St. Paul, MN, USA, 2000.

36. Qarooni, J. Flat Bread Technology; Springer Science \& Business Media: Berlin/Heidelberg, Germany, 1996 ; ISBN 0412081113.

37. Peryam, D.R.; Pilgrim, F.J. Hedonic scale method of measuring food preferences. Food Technol. 1957, 11, 9-14.

38. Sarteshnizi, R.A.; Hosseini, H.; Bondarianzadeh, D.; Colmenero, F.J. Optimization of prebiotic sausage formulation: Effect of using $\beta$-glucan and resistant starch by D-optimal mixture design approach. LWT-Food Sci. Technol. 2015, 62, 704-710. [CrossRef]

39. Ouazib, M.; Dura, A.; Zaidi, F.; Rosell, C.M. Effect of partial substitution of wheat flour by processed (germinated, toasted, cooked) chickpea on bread quality. Int. J. Agric. Sci. Technol. 2016, 11, 1. [CrossRef]

40. Al-Jahani, A.H. Effect of Buttermilk on the Physicochemical, Rheological, and Sensory Qualities of Pan and Pita Bread. Int. J. Food Sci. 2017, 2017, 2054252. [CrossRef]

41. Madenci, A.B.; Bilgiçli, N. Effect of whey protein concentrate and buttermilk powders on rheological properties of dough and bread quality. J. Food Qual. 2014, 37, 117-124. [CrossRef]

42. Alsuhaibani, A. Rheological and nutritional properties and sensory evaluation of bread fortified with natural sources of calcium. J. Food Qual. 2018, 2018, 8308361. [CrossRef]

43. Cota-Gastélum, A.G.; Salazar-García, M.G.; Espinoza-López, A.; Perez-Perez, L.M.; Cinco-Moroyoqui, F.J.; Martínez-Cruz, O.; Wong-Corral, F.J.; Del-Toro-Sánchez, C.L. Characterization of pasta with the addition of Cicer arietinum and Salvia hispanica flours on quality and antioxidant parameters. Ital. J. Food Sci. 2019, 31, 3.

44. Khan, I.T.; Nadeem, M.; Imran, M.; Ullah, R.; Ajmal, M.; Jaspal, M.H. Antioxidant properties of Milk and dairy products: A comprehensive review of the current knowledge. Lipids Health Dis. 2019, 18, 1-13. [CrossRef] [PubMed]

45. Bojňanská, T.; Urminská, D. Influence of natural additives on protein complex of bread. Potravin. Slovak J. Food Sci. 2010, 4, 1-5. [CrossRef] 
46. Yıldırım, A.; Karaboğa, Z.Y. The effects of corn and chickpea flours on the quality of mardin peksimet. In Proceedings of the International Conference on Food, Agriculture and Animal Husbandry, Gaziantep, Turkey, 19-22 September 2019.

47. Pasqualone, A.; De Angelis, D.; Squeo, G.; Difonzo, G.; Caponio, F.; Summo, C. The effect of the addition of Apulian black chickpea flour on the nutritional and qualitative properties of durum wheat-based bakery products. Foods 2019, 8, 504. [CrossRef] [PubMed]

48. Gallagher, E.; Kenny, S.; Arendt, E.K. Impact of dairy protein powders on biscuit quality. Eur. Food Res. Technol. 2005, 221, 237-243. [CrossRef]

49. Gani, A.; Broadway, A.A.; Ahmad, M.; Ashwar, B.A.; Wani, A.A.; Wani, S.M.; Masoodi, F.A.; Khatkar, B.S. Effect of whey and casein protein hydrolysates on rheological, textural and sensory properties of cookies. J. Food Sci. Technol. 2015, 52, 5718-5726. [CrossRef]

50. Stauffer, C.E. Principles of Dough Formation In CAUVAIN, SP.; YOUNG, LS Technology of Breadmaking. Lond. Blackie Acad. Prof. 1998, 11, 262-295.

51. Singh, N.; Harinder, K.; Sekhon, K.S.; Kaur, B. Studies on the improvement of functional and baking properties of wheat-chickpea flour blends. J. Food Process. Preserv. 1991, 15, 391-402. [CrossRef]

52. Sekhon, K.S.; Singh, N.; NAGI, H.P.S. Effect of pearling and blending on the bread-making properties of sprout-damaged wheat. Cereal Foods World 1992, 37, 715-724.

53. Papageorgiou, M.; Skendi, A. Flour Quality and Technological Abilities; Engineering Aspects of Cereal and Cereal-Based Products; Taylor \& Francis Group, LLC.: Philadelphia, PA, USA, 2014; pp. 117-148.

54. Gallagher, E.; Gormley, T.R.; Arendt, E.K. Recent advances in the formulation of gluten-free cereal-based products. Trends Food Sci. Technol. 2004, 15, 143-152. [CrossRef]

55. Yamsaengsung, R.; Schoenlechner, R.; Berghofer, E. The effects of chickpea on the functional properties of white and whole wheat bread. Int. J. Food Sci. Technol. 2010, 45, 610-620. [CrossRef]

56. Sanchez, H.D.; Osella, C.A.; De La Torre, M.A. Use of response surface methodology to optimize gluten-free bread fortified with soy flour and dry milk. Food Sci. Technol. Int. 2004, 10, 5-9. [CrossRef]

57. Sharma, A.; Jana, A.H.; Chavan, R.S. Functionality of milk powders and milk-based powders for end use applications-A review. Compr. Rev. Food Sci. Food Saf. 2012, 11, 518-528. [CrossRef]

58. Miñarro, B.; Albanell, E.; Aguilar, N.; Guamis, B.; Capellas, M. Effect of legume flours on baking characteristics of gluten-free bread. J. Cereal Sci. 2012, 56, 476-481. [CrossRef]

59. Edwards, W.P. The Science of Bakery Products; Royal Society of Chemistry: Cambridge, UK, 2007; ISBN 1847557791. 